\title{
NIH institute limits scope of 'AIDS research'
}

Washington. Following two critical reports, the National Cancer Institute (NCI) has moved quickly to increase the proportion of AIDS research money awarded to extramural scientists and tighten the definition of AIDS-related research. Both moves, say observers, have made it less vulnerable to Congressional Republicans opposed to earmarking money for AIDS.

More than 10 per cent of the NCI's annual budget of $\$ 2.2$ billion is spent on AIDS research. Addressing the National Cancer Advisory Board last week, Richard Klausner, who was appointed director of the institute last August, said that over the past nine months, a "dramatic" change had been made in how this money is distributed.

In particular, 1996 funding for external researchers, especially in the fields of human immunology and the viral aetiology of AIDS-related malignancies, has increased by 178 per cent, from $\$ 37$ million to $\$ 104$ million. In contrast, funding for intramural projects has been cut from $\$ 102$ million to $\$ 66$ million. Much of this research has been reclassified, and is now supported by cancer - rather than AIDS - funds. Additional cuts of $\$ 32$ million have been made in contract work primarily supporting intramural AIDS research.

According to Klausner, the changes rectify an "indefensible imbalance" in favour of intramural work that existed a year ago, when a working group headed by $\mathbf{J}$. Michael Bishop of the University of California, San Francisco, and Paul Calabresi of Brown University in Providence, Rhode Island, recommended a major overhaul of $\mathrm{NCI}$ management (see Nature, 375, 267; 1995).

The working group called the definition of AIDS research at the cancer institute too broad, leading to between 30 and 35 per cent of the institute's intramural work being labelled as AIDS research. The report called for an "expeditious and comprehensive" review of all AIDS research conducted by the NCI, saying that the institute should "wean" itself from much of this, and only retain "truly meritorious" research on AIDS. Money freed up in this way, it said, should go to extramural AIDS work.

These conclusions were echoed in a second major report, prepared by a 118-member panel led by Arnold Levine, a Princeton University molecular biologist, and published in March (see Nature 380, 190; 1996).

Klausner said last week that his institute has agreed to a new coding system for AIDS-related research. Under this, 'direct' research, defined as that involving the AIDS virus or HIV-infected patients, will be fully funded by AIDS dollars.

Research 'applicable' to AIDS - such as studies on Kaposi's sarcoma and central nervous system lymphomas - will be judged on a case-by-case basis and receive between
30 and 70 per cent AIDS funding. 'Fundamental' research that pertains to AIDS in fields such as virology and immunology will be supported with between 10 and 20 per cent AIDS money.

Klausner said that NCI officials were wary of claiming an ability to advance AIDS research by sitting "around a table" and producing a precise definition of relevant science. But, he said, "we do need to be able to intellectually defend the choices we make".

Some research projects in mouse T-cell development, for example, previously supported by AIDS money, are now being financed from the institute's cancer budget. The money freed in this way has been redirected to extramural researchers working on human immunology - a field that the Levine report said needed more attention.

The changes are significant both because the NCI is by far the largest of the NIH's 24 institutes, divisions and centres, consuming almost one-fifth of the total NIH budget, and because it has recently come under fire for sloppy accounting, poor management, minimal investigator accountability and weak strategic planning.

According to Klausner, all that is now changing. Measures he has introduced include an increased focus on AIDS-related malignancies, overseen by a new AIDS
Malignancies Working Group. The NCI is also establishing a Center for AIDS Research to co-ordinate basic science AIDS research at the institute. Intramural investigators have also been made more accountable for the quality of their work.

The changes will help to meet one concern of the cancer institute's supporters, raised by Bishop at last week's meeting: the institute's vulnerability to political currents on Capitol Hill. Some Congressional Republicans oppose the notion of earmarking money for AIDS research, arguing that scientists - and not legislators - should determine how research funds are divided between medical priorities.

Since 1993, however, Congress has mandated that money for AIDS research be earmarked as such, and the NIH's AIDS budget now stands at $\$ 1.4$ billion. If this policy were to be reversed by Republicans, the NCI would, before this year, have been "deeply at risk" Bishop said, because of its reliance on earmarked AIDS money for fully one third of its intramural work. But according to Klausner's figures, the recent changes have meant that AIDS money now funds only 16 per cent of such work. Any policy change would therefore affect his institute "very little", he said at the meeting.

Meredith Wadman

\section{Darwin's house bought for restoration}

London. The future of

Down House (right),

the home of Charles

Darwin for $\mathbf{4 0}$ years

until his death in

1882 and in which he

wrote On the Origin

of Species, has been

secured thanks to

the UK National Lot-

tery, with help from

the Wellcome Trust

and the Natural History Museum in London's South Kensington.

The Kent residence and its historical contents, which had fallen into disrepair, have been bought by English Heritage, a government body that looks after many of Britain's historic buildings, with $£ 705,000$ (US\$1.06 million) in two grants from the Wellcome Trust.

The house, which has 5,000 visitors a year, has now been closed, and will reopen as a museum and educational resource centre in June 1997. The restoration will be paid out of a $£ 1.78$ million grant from the National Lottery and $£ 625,000$ raised by the Natural History Museum.

The house has more than $\mathbf{3 0}$ acres

of gardens and parkland, and has been owned since 1953 by the Royal College of Surgeons. But the college was keen to find another owner, as the house was too expensive to maintain. The Natural History Museum took over the administration of Down House in 1993 for three years, and had an option to retain a 99-year lease on the property. But negotiations between the museum and the college were unsuccessful, and the college began to look for alternative buyers.

Neil Chalmers, the director of the museum and Roger Gibbs, chairman of the board of the Wellcome Trust both say they are "delighted" with the eventual outcome. Ehsan Masood 